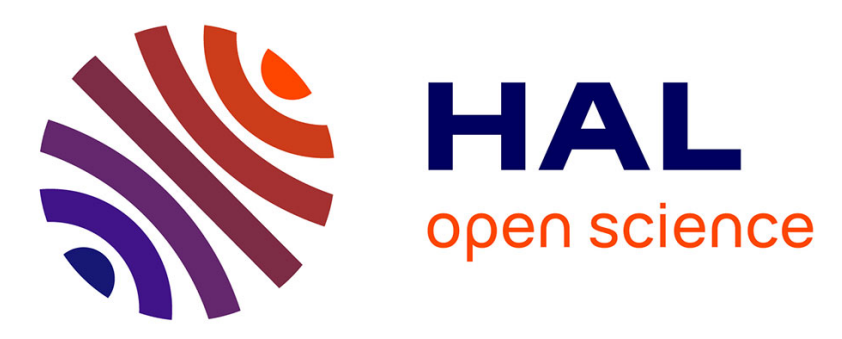

\title{
How the Anchoring Site on Two Extended Tetrathiafulvalenes Impacts the Electronic Communication through a Bis(acetylide)ruthenium Linker
}

\author{
Hadi Hachem, Antoine Vacher, Vincent Dorcet, Dominique Lorcy
}

\section{To cite this version:}

Hadi Hachem, Antoine Vacher, Vincent Dorcet, Dominique Lorcy. How the Anchoring Site on Two Extended Tetrathiafulvalenes Impacts the Electronic Communication through a Bis(acetylide)ruthenium Linker. Organometallics, 2017, 36 (11), pp.2208-2217. 10.1021/acs.organomet.7b00257 . hal01559206

\section{HAL Id: hal-01559206 \\ https://hal-univ-rennes1.archives-ouvertes.fr/hal-01559206}

Submitted on 13 Sep 2017

HAL is a multi-disciplinary open access archive for the deposit and dissemination of scientific research documents, whether they are published or not. The documents may come from teaching and research institutions in France or abroad, or from public or private research centers.
L'archive ouverte pluridisciplinaire HAL, est destinée au dépôt et à la diffusion de documents scientifiques de niveau recherche, publiés ou non, émanant des établissements d'enseignement et de recherche français ou étrangers, des laboratoires publics ou privés. 


\title{
How the anchoring site on two extended tetrathiafulvalenes impacts the electronic communication through a bis(acetylide)ruthenium linker
}

\author{
Hadi Hachem, Antoine Vacher, Vincent Dorcet, Dominique Lorcy* \\ Institut des Sciences Chimiques de Rennes, UMR 6226 CNRS-Université de Rennes 1, Campus de \\ Beaulieu, Bât 10A, 35042 Rennes cedex, France. Tel: 3322323 6273; E-mail: \\ Dominique.lorcy@univ-rennes1.fr,orcid.org/0000-0002-7698-8452
}

\begin{abstract}
:
The interplay between two extended tetrathiafulvalenes connected, either from the dithiole rings or the anthraquinodimethane moieties, through a bis(acetylide) ruthenium linker has been studied within the novel complexes trans$\left[\mathrm{Ru}(\mathrm{C} \equiv \mathrm{CDTTFAQ})_{2}(\mathrm{dppe})_{2}\right] \quad$ and $\quad$ trans-

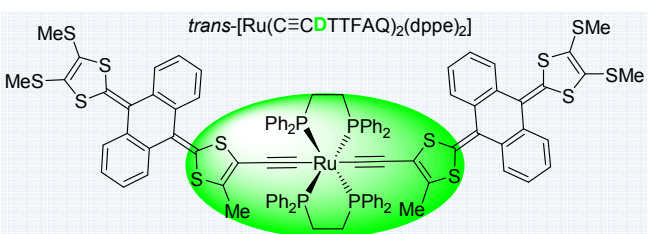
$\left[\mathrm{Ru}(\mathrm{C} \equiv \mathrm{CATTFAQ})_{2}(\mathrm{dppe})_{2}\right]$. Cyclic voltammetry and spectro-electrochemical investigations evidence that the organic and inorganic electrophores are electronically coupled within these complexes. Moreover, the electronic communication between the two organic electrophores depends on the localization of the anchoring site of the organometallic bis(acetylide) ruthenium linker on the organic electrophores.
\end{abstract}

\section{Introduction}


Extended tetrathiafulvalenes, where two 1,3-dithiole rings are connected in 2-position by an anthraquinodimethane core (TTFAQs), have focused a lot of the attention as building blocks for the design of molecular materials for artificial photosynthesis and photovoltaics, ${ }^{1,2}$ molecular receptors, ${ }^{3}$ molecular tweezers for $\mathrm{C}_{60}{ }^{4}$ or metal ions. ${ }^{5}$ The TTFAQ is a redox active moiety which exhibits pronounced structural changes associated with electron transfer. ${ }^{6,7}$ Indeed, in the neutral state, due to steric hindrance, the molecule adopts a saddle/butterfly shape, while in the dicationic state, the generated anthracene central part becomes planar with the two dithiole moieties localized in perpendicular planes. ${ }^{8}$ This molecular motion concerted with the electron transfer leads to pseudo reversible cyclic voltammogram where the compound oxidizes into the dication with potential inversion. ${ }^{9,10}$ TTFAQ dimers have also been synthetized either as macrocyclic receptors for $\mathrm{C}_{60}$ recognition ${ }^{11,12}$ or as positive electrode materials for rechargeable batteries. ${ }^{13}$ In order to form TTFAQ dimers, different strategies have been used: either the two redox active cores are directly connected to each other, or a spacer group is used. Moreover, the link between the two TTFAQ moieties can be localized either between two dithiole rings or between two anthraquinodimethane cores. Two different redox behaviors are observed: dimers where both TTFAQ are oxidized simultaneously and dimers where each electroactive core is oxidized sequentially. This second case is scarce. ${ }^{13,14}$ On the one hand, when the two donor moieties are covalently attached by the anthracene cores with a spacer (A in chart 1), such as an oxygen atom, ${ }^{15}$ an ethene ${ }^{16}$, alkyne ${ }^{17,18}$ or more recently a Pt bis(acetylide) linker, ${ }^{12}$ both TTFAQ are oxidized simultaneously and no electronic interplay has been evidenced. On the other hand, when the TTFAQs are linked directly through the dithiole moieties (B and C chart 1), two closely spaced redox processes are observed, indicating intramolecular electronic interactions between the donor units. ${ }^{14}$ 


\section{Chart 1}

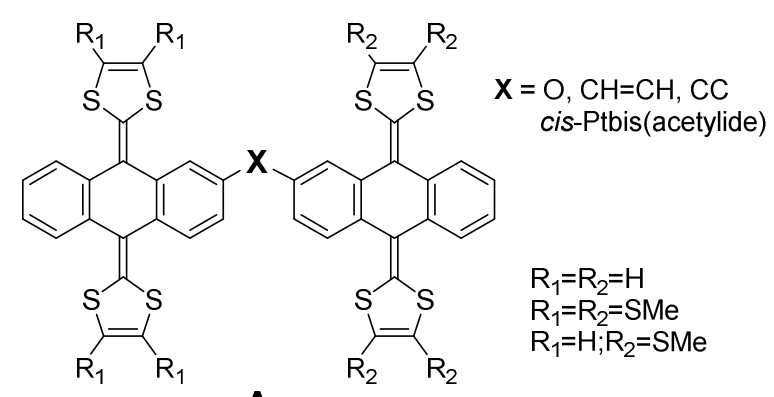

A

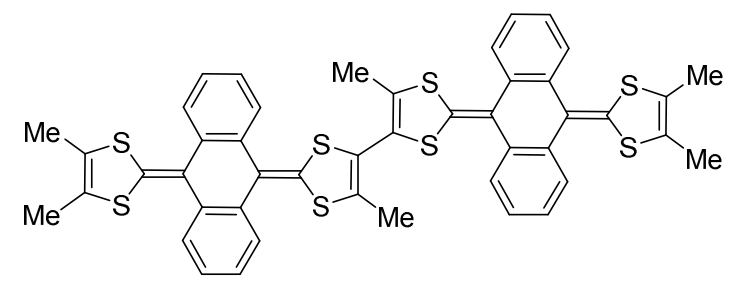

B

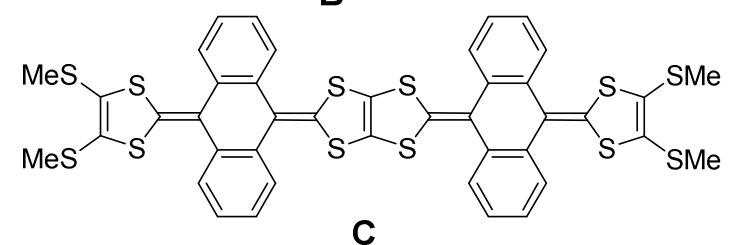

Recently, we reported the synthesis of TTF dimers where the two redox active cores are connected by an organometallic linker the trans-Ru-bis(acetylide) and we demonstrated that electronic communication occurs between the three redox active cores, i.e. the two TTF and the $\mathrm{Ru}$ centre within trans- $\left[\mathrm{Ru}\left(\mathrm{C} \equiv \mathrm{CMe}_{3} \mathrm{TTF}\right)_{2}(\mathrm{dppe})_{2}\right] .{ }^{19}$ The bis(acetylide)ruthenium linker is indeed known to promote the electronic interactions in both the $\mathrm{Fc}^{20}$ and $\mathrm{TTF}^{19}$ series. Thus, we decided to investigate similar TTFAQ dimers, trans- $\left[\mathrm{Ru}(\mathrm{C} \equiv \mathrm{CTTFAQ})_{2}(\mathrm{dppe})_{2}\right]$ (Chart 2). In order to analyze the effect of the anchoring site of the organometallic fragment on the electronic interplay, we prepared two types of complex, either the one where the bis(acetylide)ruthenium linker is covalently attached to the dithiole ring of each donor, trans$\left[\mathrm{Ru}(\mathrm{C} \equiv \mathrm{CDTTFAQ})_{2}(\mathrm{dppe})_{2}\right]$ noted as $\mathrm{D}-\mathrm{Ru}-\mathrm{D}$, or to the anthraquinodimethane core of the donor, trans- $\left[\mathrm{Ru}(\mathrm{C} \equiv \mathrm{CATTFAQ})_{2}(\mathrm{dppe})_{2}\right]$ noted as A-Ru-A (Chart 2). 


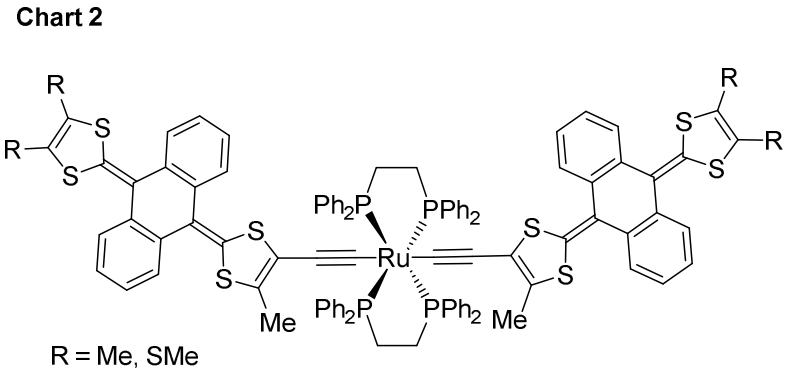

trans-[Ru(C $\left.=\mathrm{CDTTFAQ})_{2}(\mathrm{dppe})_{2}\right]$

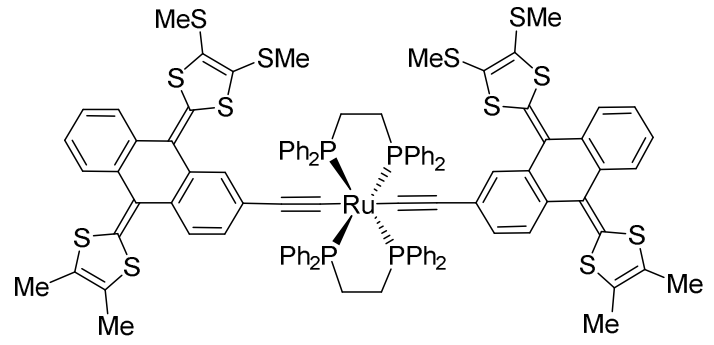

trans-[Ru(CECATTFAQ $\left.)_{2}(\text { dppe })_{2}\right]$

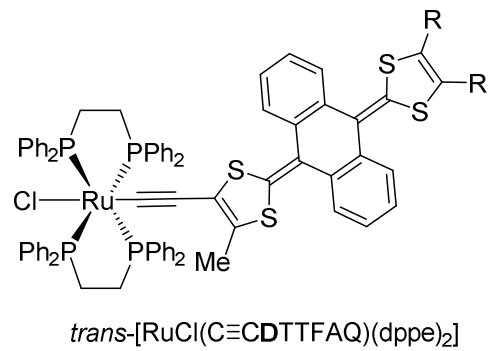

Herein, we report the synthesis of the two types of TTFAQ dimers and their electrochemical and spectroelectrochemical investigations, in order to characterize the electronic interactions between the TTFAQ units. In addition, to gain a better insight into the possible interaction between $\mathrm{Ru}$ and the TTFAQ, we also synthetized and characterized the mono substituted complex, where only one donor core is connected to the Ru atom via an alkyne bridge, trans-[RuCl(C $\left.\equiv \mathrm{CDTTFAQ})(\mathrm{dppe})_{2}\right]$ noted as $\mathrm{D}-\mathrm{Ru}$ (chart 2).

\section{Results and Discussion}

The target alkyne derivatives 3a-b were prepared starting from the iodo-TTFAQ 1a-b according to the chemical route described in Scheme 1. Sonogashira type reaction between $1 \mathbf{a}^{14}-\mathbf{b}$ and trimethylsilylacetylene catalyzed by $\mathrm{CuI}$ and $\mathrm{PdCl}_{2}\left(\mathrm{PPh}_{3}\right)_{2}$ in the presence of diisopropylamine afforded $\mathbf{2 a - b}$ in good yields. Deprotection of the alkyne, perfomed by adding KF into a solution of $\mathbf{2 a - b}$ in $\mathrm{MeOH}$, afforded TTFAQ 3a-b in quantitative yields. 


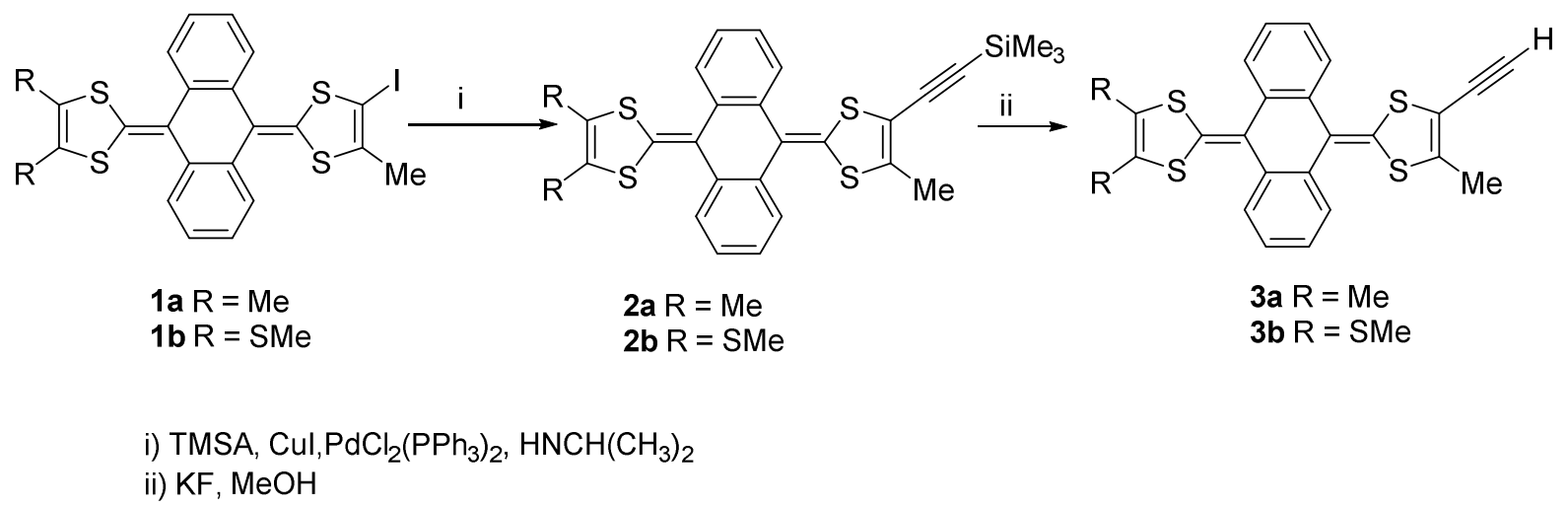

Scheme 1. Synthesis of the TTFAQ-ethyne 3a-b.

Crystals of 3a suitable for X-ray diffraction study were grown by slow concentration of chloroform solution. TTFAQ 3a crystallizes with one molecule of $\mathrm{CHCl}_{3}$ and the molecular structure of 3a is represented in Figure 1. The TTFAQ exhibits a saddle like shape with bond lengths and bond angles of the TTFAQ core itself in the usual range for such derivatives. ${ }^{8,21}$ The $\mathrm{C} \equiv \mathrm{C}$ distance in 3a $(1.151(7) \AA)$ is comparable with that of Me $\mathrm{M}_{3} \mathrm{TTF}-\mathrm{ethyne}(1.152(8)$ $\AA) .{ }^{19}$

a)

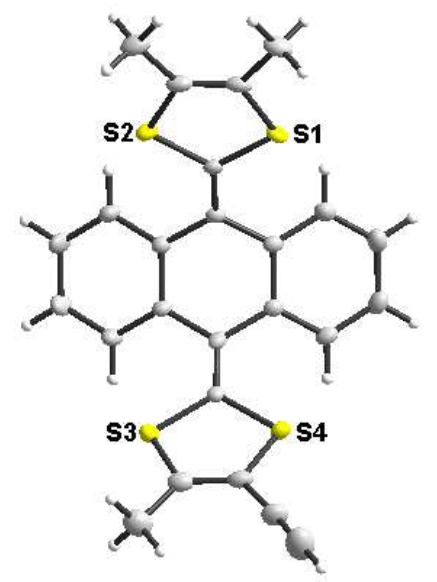

b)

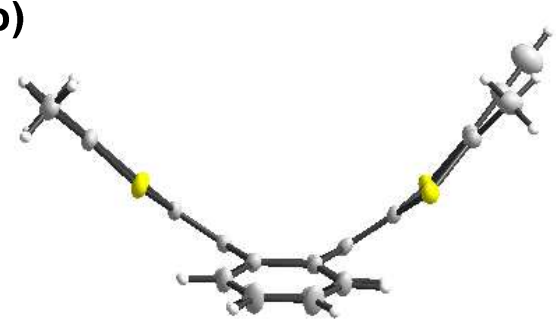

Figure 1. Molecular structure of 3a (a) showing thermal ellipsoids at $50 \%$ probability level (b) side view. 
The synthesis of trans- $\left[\mathrm{RuCl}(\mathrm{C} \equiv \mathrm{CDTTFAQ})(\mathrm{dppe})_{2}\right] \mathbf{5 a - b}, \mathrm{D}-\mathrm{Ru}$, is based on the reaction of TTFAQ-ethyne 3a-b with $\left[\mathrm{ClRu}(\mathrm{dppe})_{2}\right][\mathrm{OTf}]$ in dichloromethane at room temperature under inert atmosphere (scheme 2). The progress of the reaction was monitored by ${ }^{31} \mathrm{P}$ NMR: the two triplets of $\left[\mathrm{ClRu}(\mathrm{dppe})_{2}\right][\mathrm{OTf}]$ at 84.9 and $57.1 \mathrm{ppm}$ gradually disappear, and a new singlet appears at $\delta 46.5$ and $46.6 \mathrm{ppm}$ for $\mathbf{4 a}$ and $\mathbf{4 b}$ respectively. This singlet is assigned to a vinylidene intermediate $\mathbf{4 a - b}$ that could be isolated as a greenish powder. To reach the desired complex, deprotonation of the vinylidene was achieved via the addition of triethylamine under inert atmosphere. After the addition of base, an immediate change of color from green to yellow was observed, and the complexes trans- $\left[\mathrm{RuCl}(\mathrm{C} \equiv \mathrm{CDTTFAQ})(\mathrm{dppe})_{2}\right] \quad \mathbf{5 a - b}$ were obtained as yellowish solid (scheme 2). ${ }^{31} \mathrm{P}$ NMR showed the presence of two close multiplets at $\delta 50.7$ and $50.1 \mathrm{ppm}$ for $\mathbf{5 a}$ (Figure S1) and $\delta 49.7$ and $48.6 \mathrm{ppm}$ for $\mathbf{5 b}$. This result might be explained by the adoption of a favored position in space for the TTFAQ molecule which results in the slight break of symmetry between the phosphorus atoms.

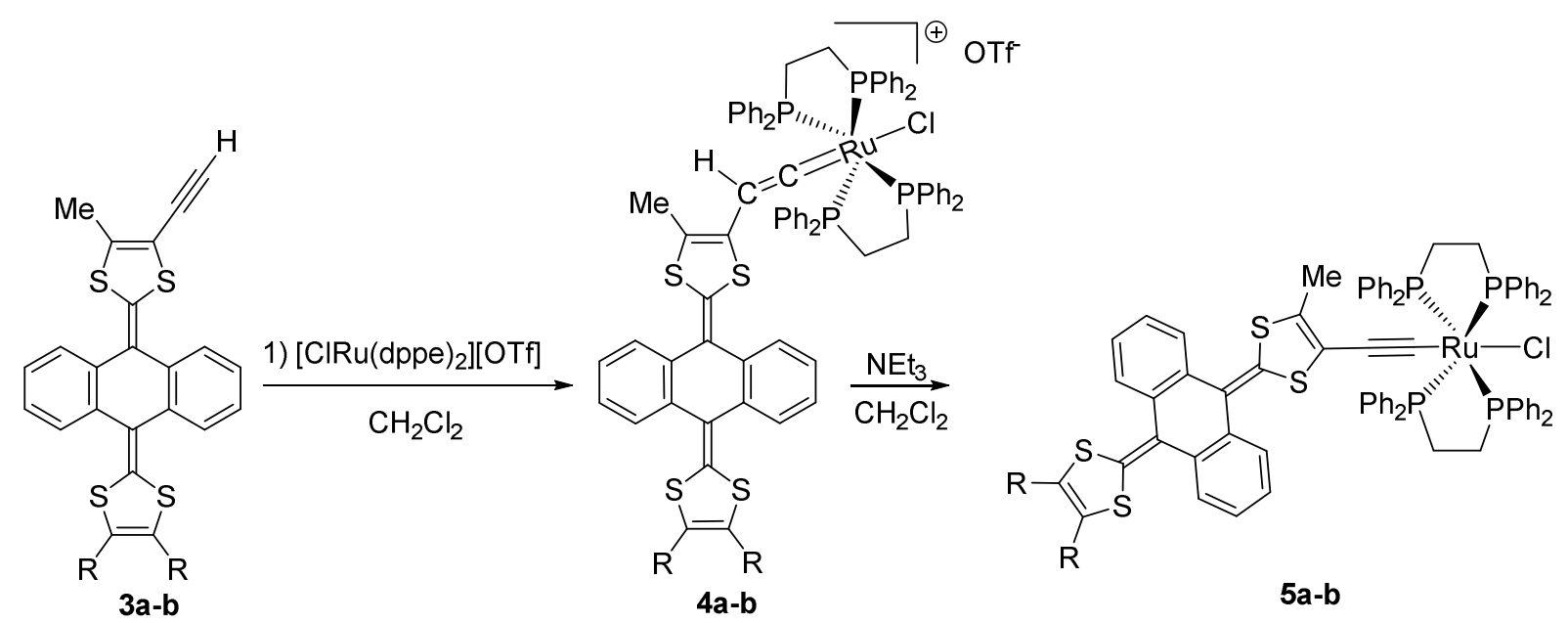

Scheme 2. Synthesis of trans $-\left[\operatorname{RuCl}(\mathrm{C} \equiv \mathrm{CDTTFAQ})(\mathrm{dppe})_{2}\right] \quad$ 5a-b $(\mathbf{a}: \mathrm{R}=\mathrm{Me}, \mathbf{b}: \mathrm{R}=\mathrm{SMe})$.

The dimeric TTFAQ complexes D-Ru-D 6a-b were synthesized by the reaction of TTFAQ alkyne 3a-b with cis- $\mathrm{Cl}_{2} \mathrm{Ru}(\mathrm{dppe})_{2}$ in the presence of $\mathrm{NaPF}_{6}$ and $\mathrm{NEt}_{3}$ under inert atmosphere 
at room temperature in dichloromethane (Scheme 3). Complex 6a was obtained as a yellow powder, insoluble in common organic solvents, while the presence of the SMe groups on the TTFAQ cores slightly increases the solubility of $\mathbf{6 b} .{ }^{31} \mathrm{P}$ NMR spectrum of the later complex shows one singlet at $\delta 51.8 \mathrm{ppm}$ indicating equivalent phosphorus surrounding and a trans arrangement of the acetylide ligands around the metallic center.

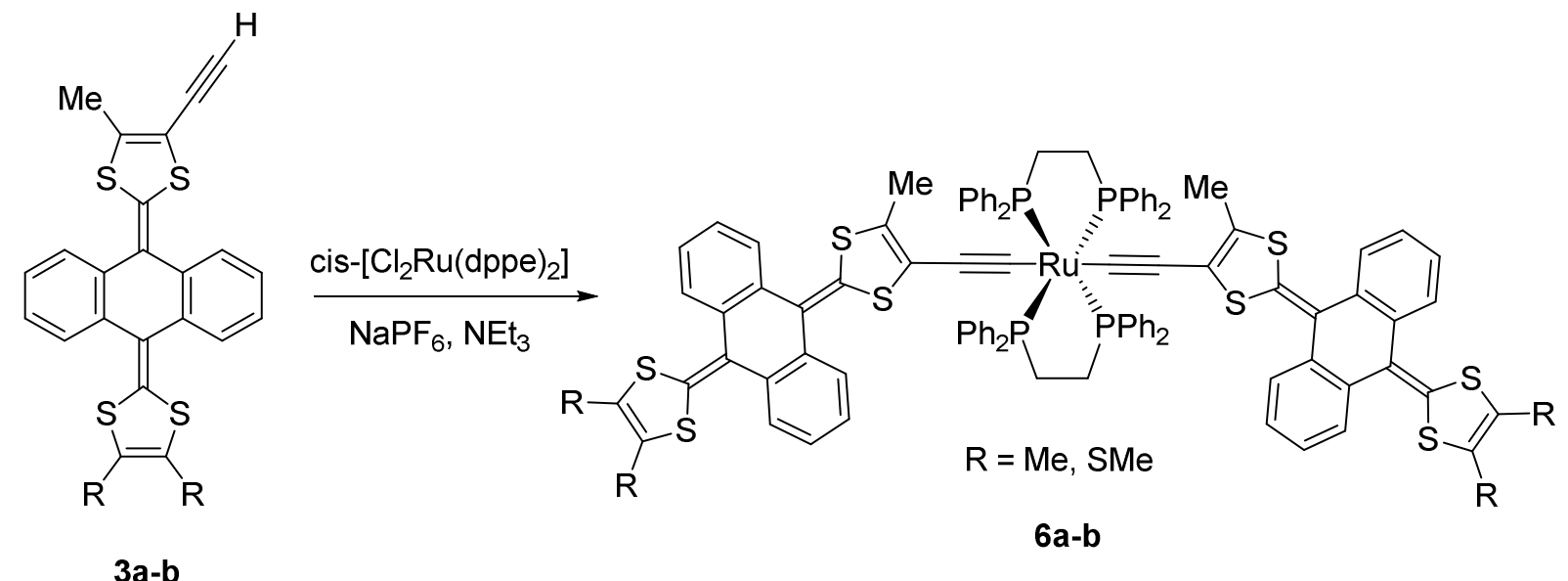

Scheme 3. Synthesis of trans $-\left[\mathrm{Ru}(\mathrm{C} \equiv \mathrm{CDTTFAQ})_{2}(\mathrm{dppe})_{2}\right] \quad \mathbf{6 a - b}(\mathbf{a}: \mathrm{R}=\mathrm{Me}, \mathbf{b}: \mathrm{R}=\mathrm{SMe})$.

In order to analyze the effect of the localization of the connection on the donor core on the electronic properties of the complex, we also prepared the reference complex A-Ru-A 8 where the two TTFAQs are linked by the organometallic bridge connected to the anthracene core. This was carried out using similar conditions as the one described above for $\mathbf{6 a}-\mathbf{b}$ but using TTFAQ-ethyne 7 with cis- $\mathrm{Cl}_{2} \mathrm{Ru}(\mathrm{dppe})_{2}$ in the presence of $\mathrm{NaPF}_{6}$ and $\mathrm{NEt}_{3}$ (Scheme 4). ${ }^{31} \mathrm{P}$ NMR spectrum of this complex shows one singlet at $\delta 53.9 \mathrm{ppm}$, confirming a trans arrangement as observed for the previous complex D-Ru-D 6b. Nevertheless, this signal is observed at lower field than for D-Ru-D $\mathbf{6 b}$ due to the localization of the anchoring site on the anthraquinone moiety which exerts a less electron releasing effect than the dithiole ring. Complex 8 was obtained in $45 \%$ yield as an orange powder. 

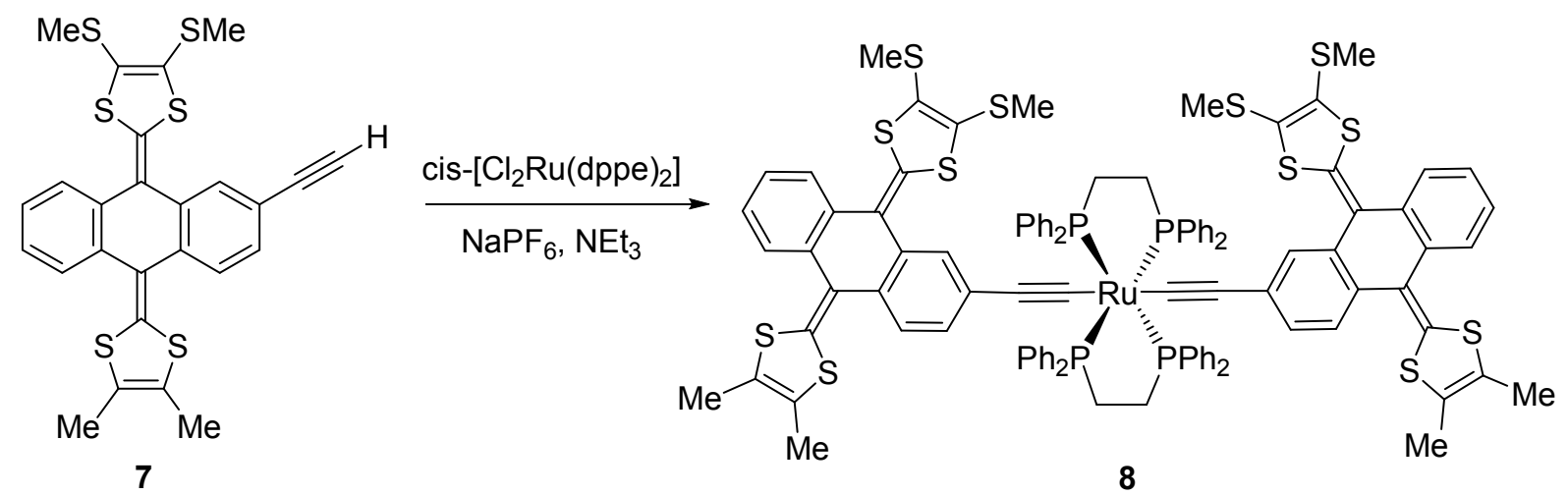

Scheme 4. Synthesis of trans- $\left[\mathrm{Ru}(\mathrm{C} \equiv \mathrm{CATTFAQ})_{2}(\mathrm{dppe})_{2}\right] \mathbf{8}$.

IR spectroscopy.

The stretching frequency of the alkyne bond measured with IR spectroscopy gives preliminary insights on the degree of conjugation between the redox active moities. TTFAQethyne 3a-b exhibit IR stretching vibration bands localized at $v_{\mathrm{C} \equiv \mathrm{C}}=2095-2096 \mathrm{~cm}^{-1}$ respectively. In complexes D-Ru 5a and D-Ru-D 6a-b, the $v_{C=C}$ stretching frequency is found at $2044 \mathrm{~cm}^{-1}$, close to the one found for the trans- $\left[\mathrm{Ru}\left(\mathrm{C} \equiv \mathrm{CMe}_{3} \mathrm{TTF}\right)_{2}(\mathrm{dppe})_{2}\right]^{19}$ and trans$\left[\mathrm{RuCl}\left(\mathrm{C} \equiv \mathrm{CMe}_{3} \mathrm{TTF}\right)(\mathrm{dppe})_{2}\right]^{22}$ complexes $\left(2033\right.$ and $2029 \mathrm{~cm}^{-1}$ respectively). This indicates a high degree of conjugation in all these Ru complexes, D-Ru 5a-b and D-Ru-D 6a-b. The IR spectrum of A-Ru-A 8 reveals a stretching vibration band at $2053 \mathrm{~cm}^{-1}$, characteristic of aromatics linked to the ruthenium atom via an acetylide bridge. ${ }^{23}$ The $v_{\mathrm{C} \equiv \mathrm{C}}$ stretching frequencies of complexes D-Ru-D 6a-b where the connection occurs through the dithiole ring, is lower by $10 \mathrm{~cm}^{-1}$, due to a higher electron donor character of the dithiole ring than the anthraquinodimethane moiety. Similar influences were already observed on the ${ }^{31} \mathrm{P}$ NMR spectra of these complexes (see above).

Single crystals of complex D-Ru-D $\mathbf{6 b}$ were obtained by slow diffusion of pentane into a concentrated solution of $\mathbf{6 b}$ in chloroform and carbon disulfide (3/1) under an inert atmosphere. The molecular structure of $\mathbf{6 b}$, presented in Figure 2, shows that two TTFAQacetylide ligands are coordinated to the ruthenium center in a trans arrangement. The $\mathrm{Ru}-$ bis(acetylide) spacer is almost linear with angles at $\mathrm{C} \alpha-\mathrm{Ru}-\mathrm{C} \alpha, \mathrm{Ru}-\mathrm{C} \alpha \equiv \mathrm{C} \beta$ and 
$\mathrm{C} \alpha \equiv \mathrm{C} \beta-\mathrm{CTTF}$ of $180.00^{\circ}, 174.33^{\circ}$ and $175.27^{\circ}$ respectively. The $\mathrm{Ru}-\mathrm{C}$ distance of $2.065(4)$ $\AA$ and the $\mathrm{C} \equiv \mathrm{C}$ bond length of $1.212(5) \AA$ for $\mathbf{6 b}$ are similar to those observed for trans$\left[\mathrm{Ru}\left(\mathrm{C} \equiv \mathrm{CMe}_{3} \mathrm{TTF}\right)_{2}(\mathrm{dppe})_{2}\right](2.069(3) \AA$ and $1.203(3) \AA$ respectively $) .{ }^{19}$ As already noticed for other Ru bis(acetylide) complexes, the alkyne bond in the D-Ru-D complex $\mathbf{6 b}$ is much longer than in TTAFQ 3a (1.151(7) A). As observed in Figure 2 both TTFAQ cores exhibit the classical saddle like shape.
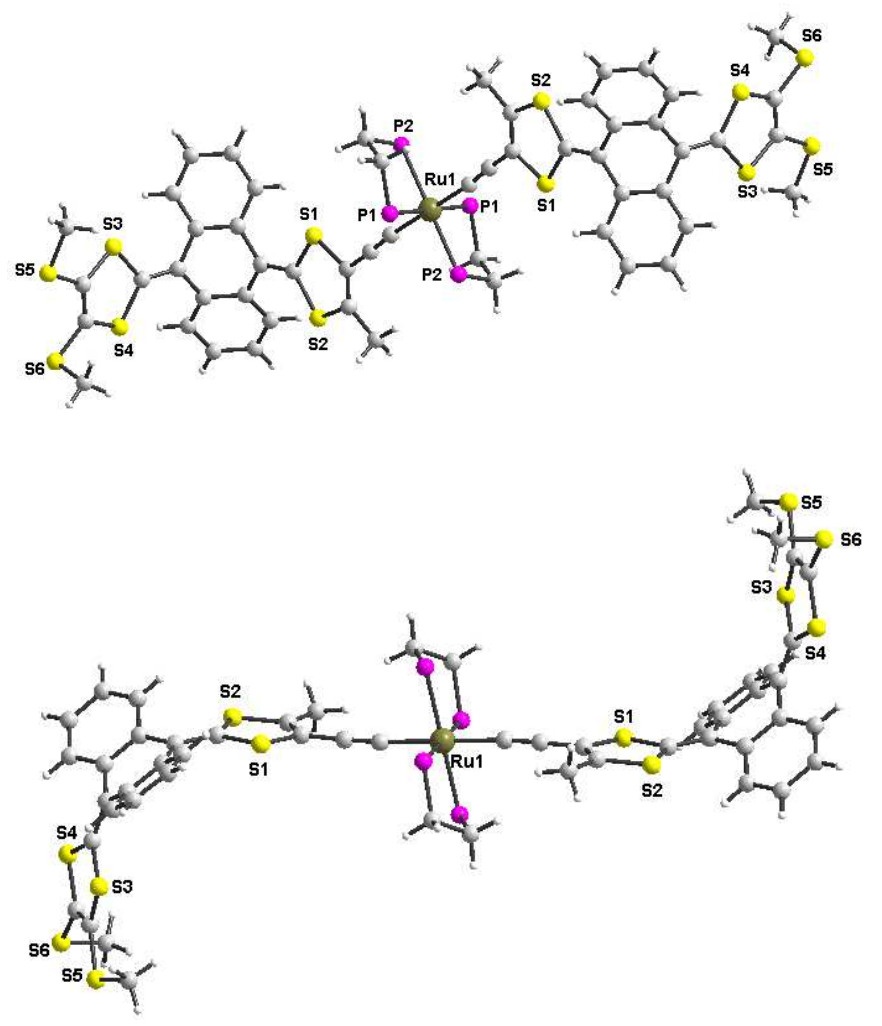

Figure 2. Two views of the molecular structure of trans- $\left[\mathrm{Ru}(\mathrm{C} \equiv \mathrm{CDTTFAQ})_{2}(\mathrm{dppe})_{2}\right] \mathbf{6 b}$. The phenyl substituants of the two dppe ligands have been omitted for clarity.

\section{Electrochemical properties}

The redox properties of the TTFAQ derivatives 1a-b, 3a-b, 7 and the complexes D-Ru 5a-b, D-Ru-D $6 \mathbf{b}$ and A-Ru-A 8 were studied by cyclic voltammetry (CV), performed in $\mathrm{CH}_{2} \mathrm{Cl}_{2}$ containing $0.1 \mathrm{M}$ of $\mathrm{Bu}_{4} \mathrm{NPF}_{6}$ as supporting electrolyte. The redox potentials are given in $\mathrm{V} v s$ 
$\mathrm{Fc} / \mathrm{Fc}^{+}$and are collected in Table 1 . The CVs of the starting TTFAQs $\mathbf{1 - 3}$ and $\mathbf{7}$ exhibit a single two-electron, quasi-reversible oxidation wave corresponding to the oxidation of the TTFAQ from the neutral state to the dication (Figure 3) which is the typical behavior observed for such TTFAQ donors. ${ }^{24,25}$ The differences between the anodic and the cathodic peak potentials $\left(\Delta \mathrm{E}_{\mathrm{p}}=\mathrm{E}_{\mathrm{Pa}}-\mathrm{E}_{\mathrm{Pc}}\right)$ amount to $290-210 \mathrm{mV}$ for the different TTFAQs studied at $100 \mathrm{mV} / \mathrm{s}$. The large separation between the anodic and cathodic peaks is generated by the major conformational change that accompanies the electron-transfer process. It is a typical example of inverted potentials in a two-electron process, where it is easier to remove the second electron than the first one. ${ }^{9}$ The redox potentials do not vary significantly for compounds $\mathbf{1}$ to $\mathbf{3}$ indicating the similar influence of the iodo substituent (1) and the alkyne one (2-3). Between the two series, $\mathbf{a}$ and $\mathbf{b}$, the thiomethyl substituents decrease slightly the overall donating ability, as the redox potentials are shift towards anodic potentials by 20 to 50 $\mathrm{mV}$. For 7, with the ethyne arm on the anthraquinodimethane moiety, substituted by two Me groups and two SMe groups, the redox properties are closed to the one observed for $\mathbf{3 a}$.

Table 1 Redox potentials in $\mathrm{CH}_{2} \mathrm{Cl}_{2}$, Epa/Epc in $\mathrm{V}$ vs Fc/Fc ${ }^{+}, \Delta \mathrm{Ep}$ in $\mathrm{mV}$

\begin{tabular}{lcc}
\hline compound & $\mathrm{R}=\mathrm{Me} \mathbf{a}$ & $\mathrm{R}=\mathrm{SMe} \mathbf{b}$ \\
\hline I-TTFAQ 1 & $0.03 /-0.26(290)$ & $0.05 /-0.16(210)$ \\
Me ${ }_{3}$ SiC $\equiv$ C-TTFAQ 2 & $0.02 /-0.27(290)$ & $0.06 /-0.17(230)$ \\
H-C $\equiv$ C-TTFAQ 3 & $0.03 /-0.24(270)$ & $0.08 /-0.16(240)$ \\
H-C $\equiv$ C-TTFAQ 7 & $0.02 /-0.22(240)$ \\
D-Ru 5a & $-0.20 /-0.50(300), 0.52 / 0.45(70)$ \\
D-Ru 5a & $-0.12 /-0.37(250), 0.53 / 0.46(70)$ \\
D-Ru-D 6b & $-0.14 /-0.26(120),-0.08 /-0.18(100), 0.70 / 0.65(50)$ \\
A-Ru-A 8 & $-0.11 /-0.16(50), 0.22 / 0.29(70)$ \\
\end{tabular}


For complex D-Ru 5a-b, with one single TTFAQ moiety, two redox systems are observed on the CVs, one pseudo reversible bielectronic system $\left(\Delta E_{p}=300\right.$ and $250 \mathrm{mV}$ for $\left.\mathbf{5 a}-\mathbf{b}\right)$ and a fully reversible monoelectronic process $\left(\Delta \mathrm{E}_{\mathrm{p}} 70 \mathrm{mV}\right)$, (Figure 3). Both processes are tentatively assigned respectively to the redox signature of the TTFAQ core and the Ru organometallic fragment. The pseudo reversible system is observed at a lower potential than the one observed for the starting TTFAQ 3, with a potential shift of $200-230 \mathrm{mV}$. The second process at $0.49 \mathrm{~V}$ is thus viewed as involving essentially the $\mathrm{Ru}^{\mathrm{II}} / \mathrm{Ru}^{\mathrm{III}}$ couple. This process is anodically shifted by $430 \mathrm{mV}$ compared to the one observed for trans-[ $\left.\operatorname{RuCl}_{2}(\mathrm{dppe})_{2}\right]$ analyzed in the same conditions $(0.06 \mathrm{~V})$. This indicates that the oxidation of the metal center is strongly affected by the presence of the TTFAQ dication in its close proximity. These observations are reminiscent to those realized in the TTF series where the two electrophores, the TTF and the Ru, were strongly electronically coupled. ${ }^{19}$

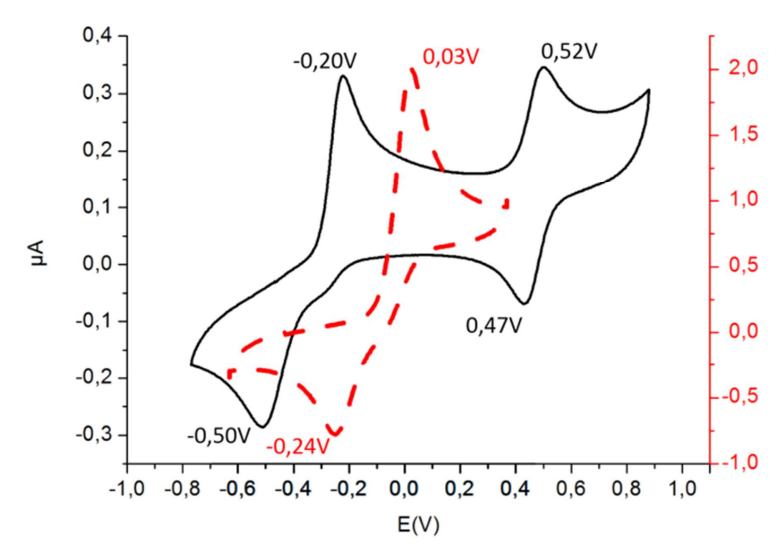

Figure 3. Cyclic voltammograms in $\mathrm{CH}_{2} \mathrm{Cl}_{2}$ with $0.1 \mathrm{M}$ of $\mathrm{Bu}_{4} \mathrm{NPF}_{6}$ at $0.1 \mathrm{~V} \mathrm{~s}^{-1}$ of complex 5a (black solid line) and 3a (red dashed line), $\mathrm{V}$ vs Fc/Fc ${ }^{+}$.

Due to solubility problems, we did not investigated the redox behavior of D-Ru-D 6a, but we analyzed the thiomethyl substituted D-Ru-D $\mathbf{6 b}$ and the CV is presented in Figure 4 together with the $\mathrm{CV}$ of the non metallated TTFAQ-ethyne $\mathbf{3 b}$ in the same experimental conditions for comparison. For D-Ru-D 6b, three clear oxidation peaks are observed indicating the stepwise 
formation of four redox states from the neutral state to the pentacation. The two first oxidation peaks are assigned to the sequential oxidation of the two TTAFQ cores to TTFAQ dications with a potential difference of $60 \mathrm{mV}$, and finally the third oxidation peaks at $0.67 \mathrm{~V}$ is attributed to the $\mathrm{Ru} \mathrm{u}^{\mathrm{II}} / \mathrm{Ru} \mathrm{III}^{\mathrm{III}}$ couple.
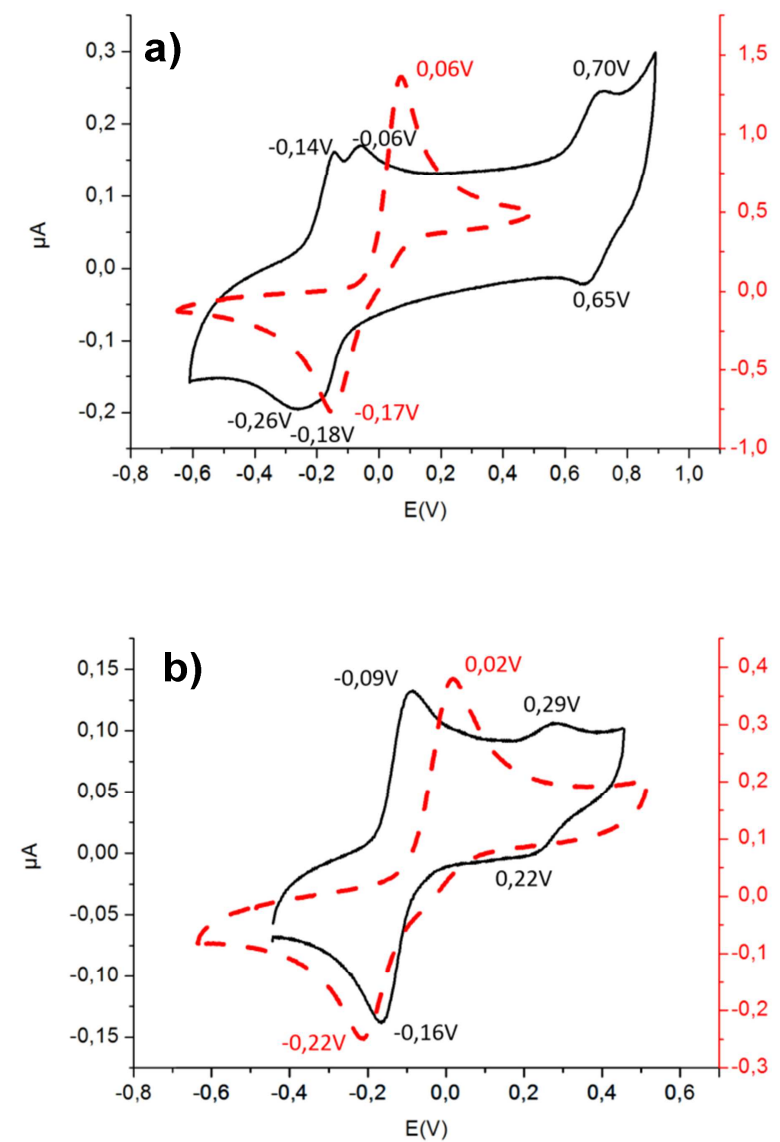

Figure 4. Cyclic voltammograms in $\mathrm{CH}_{2} \mathrm{Cl}_{2}$ with $0.1 \mathrm{M}$ of $\mathrm{Bu}_{4} \mathrm{NPF}_{6}$ at $0.1 \mathrm{~V} \mathrm{~s}^{-1}, \mathrm{~V}$ vs $\mathrm{Fc} / \mathrm{Fc}^{+}$, of a) complex D-Ru-D $\mathbf{6 b}$ (black solid line) and $\mathbf{3 b}$ (red dashed line), b) complex A-Ru-A $\mathbf{8}$ (black solid line) and the starting TTFAQ ethyne 7 (red dashed line).

As previously observed for D-Ru 5a-b, the oxidation of the two TTFAQ moieties within DRu-D $6 \mathbf{b}$ occurs at a lower potential (by $200 \mathrm{mV}$ ) than the starting TTFAQ alkyne $3 \mathbf{b}$ (Figure 4a). This can be ascribed to an increase of the electron density on the TTFAQ moiety thanks to the presence of the electron rich organometallic fragment. The existence of two close 
oxidation waves for the two TTFAQ moieties suggests a sizeable electronic interaction between the two moieties through the ruthenium bis(acetylide) linker. The last oxidation process is then assigned to the oxidation of the ruthenium, which is anodically shifted by 610 $\mathrm{mV}$ compared with the redox potentials observed for trans-[ $\left.\mathrm{RuCl}_{2}(\mathrm{dppe})_{2}\right]$. This larger shift is due to the existence of two TTFAQ, each under the dicationic state, in the close proximity of the $\mathrm{Ru}$ atom, which are acting as strong electron acceptors. Their effect is efficiently transmitted to the metal center via the acetylide linkers.

For complex A-Ru-A 8, where the site of connection to the ruthenium is located on the anthraquinodimethane ring, a fully different CV than those obtained for complexes D-Ru 5a-b and D-Ru-D 6b is observed (Figure 4b). Two reversible oxidation waves at $E^{1}=-0.13 \mathrm{~V}$ and $\mathrm{E}^{2}=0.25 \mathrm{~V}$ are attributed to the simultaneous oxidation of the two TTFAQ cores into the TTFAQ $^{2+}$, with the exchange of $4 \mathrm{e}^{-}$, followed by the oxidation of the Ru center. This result was confirmed by a DPV study where the two peaks appeared with a ratio of 4:1 (Figure S2). Thus, the connection through the central anthraquinodimethane ring of the TTFAQ does not allow, at the CV scale, the observation of interplay between the two TTFAQ cores, but it leads to a highly reversible redox process in contrast to the precursor 7. Another interesting feature is the influence of the organometallic part on the redox potentials of the TTFAQ cores. Indeed the oxidation peak potential of the TTFAQ cores within complex A-Ru-A $\mathbf{8}$ is only cathodically shifted by $100 \mathrm{mV}$ while for the previous complexes D-Ru $\mathbf{5}$ and D-Ru-D $\mathbf{6 b}$ the shift was more pronounced $(200 \mathrm{mV})$. The smaller cathodic shift observed for the redox process assigned to the TTFAQ cores indicates that the electron donating effect of the Ru is less efficiently transmitted through the anthraquinodimethane moiety. This can be easily explained by the fact that in TTFAQ, the HOMO is mainly located on the dithiole rings and the LUMO on the anthraquinodimethane unit. ${ }^{14}$ In the same vein, the oxidation potential of the $\mathrm{Ru}^{\mathrm{II}} / \mathrm{Ru}^{\mathrm{III}}$ couple is only anodically shifted by $190 \mathrm{mV}$ compared with the one observed 
for trans-[RuCl$\left.{ }_{2}(\mathrm{dppe})_{2}\right](0.06 \mathrm{~V})$ while for complex D-Ru-D $\mathbf{6 b}$ an anodic shift of $610 \mathrm{mV}$ was observed. The generation of the $\mathrm{TTFAQ}^{2+}$ induces the aromatization of the dithiolium rings together with that of the central anthracene which lies in a plane perpendicular to the planes of the dithiolium rings. Therefore the dithiolium rings act now as acceptor whose effect is weakly transmitted via the anthracene acetylide to the $\mathrm{Ru}$ center.

Spectroelectrochemical UV-vis-NIR investigations UV-vis-NIR spectra of the neutral starting alkyne 3a-b and 7 carried out on dichloromethane solution $\left(\mathrm{c} \approx 5.10^{-5} \mathrm{M}\right)$ are reported in Figure 5. The TTFAQ 3a-b exhibit two absorption bands in the UV-vis range at $\lambda_{\max }=436$ $\mathrm{nm}\left(\varepsilon=27000 \mathrm{Lmol}^{-1} \mathrm{~cm}^{-1}\right)$ and $368 \mathrm{~nm}\left(16000 \mathrm{Lmol}^{-1} \mathrm{~cm}^{-1}\right)$ for 3a, typical for TTFAQ derivatives and only a small hypsochromic shift of $4 \mathrm{~nm}$ is observed for $\mathbf{3 b}$ on each absorption bands (432 and $364 \mathrm{~nm}) .{ }^{16}$ Concerning TTFAQ 7, the presence of the ethyne fragment on the anthraquinodimethane moiety leads to a red shift of the energy transitions of 14 and $10 \mathrm{~nm}$ respectively for the two absorption bands at $450 \mathrm{~nm}\left(\varepsilon=26000 \mathrm{Lmol}^{-1} \mathrm{~cm}^{-1}\right)$ and $378 \mathrm{~nm}\left(\varepsilon=15500 \mathrm{Lmol}^{-1} \mathrm{~cm}^{-1}\right)$. Upon oxidation to the dicationic state, the two absorption bands observed in the neutral state gradually decrease in intensity, whereas a broad absorption band centered at $500 \mathrm{~nm}$ increases with an isosbestic point at $460 \mathrm{~nm}$. This absorption band is characteristic of the TTFAQ ${ }^{2+}$ absorption. ${ }^{26}$ Very similar evolution of the spectra was already observed upon oxidation of a TTFAQ derivative. ${ }^{14}$ 

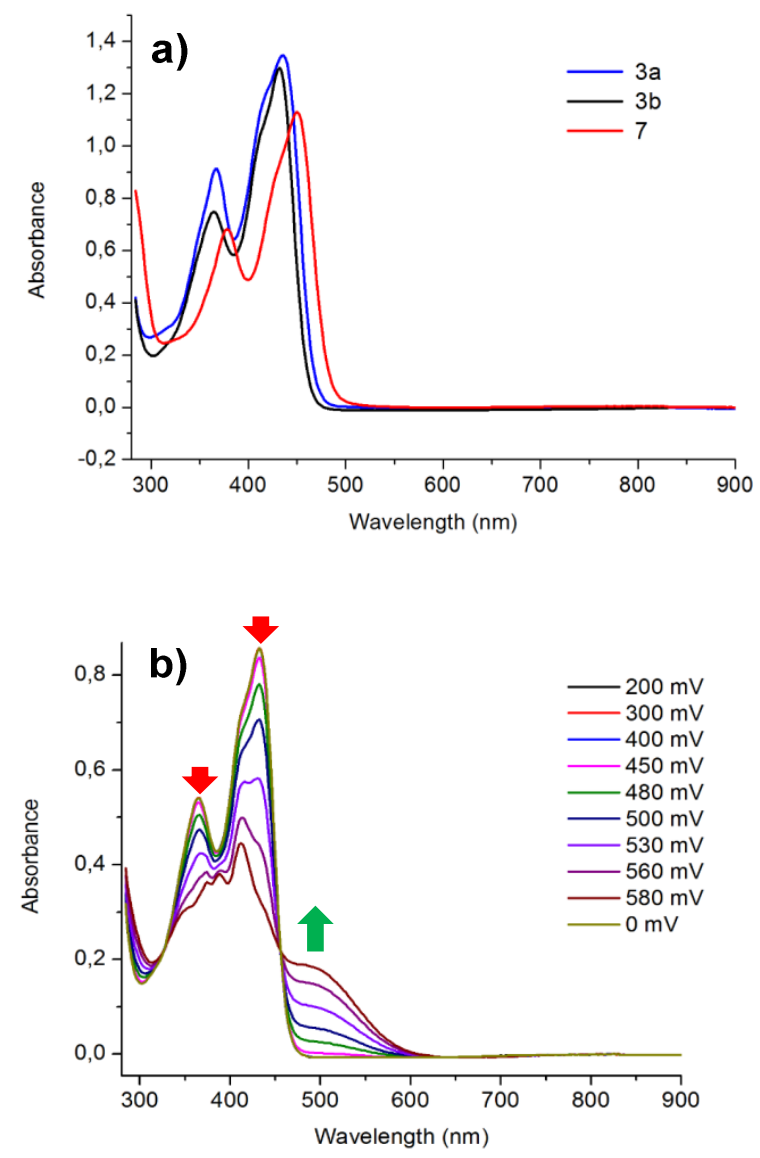

Figure 5 a) UV-vis-NIR spectra of TTFAQ-ethyne $\mathbf{3 a}, \mathbf{3 b}$, and 7, b) UV-vis-NIR monitoring of the electrochemical oxidation of $\mathbf{3 b}$ in $\mathrm{CH}_{2} \mathrm{Cl}_{2}$ containing $0.2 \mathrm{M} \mathrm{Bu}_{4} \mathrm{NPF}_{6}$, potentials are quoted vs SCE.

Spectroelectrochemical UV-vis-NIR investigations were also carried out on metal complexes D-Ru 5a, D-Ru-D 6b and A-Ru-A 8 in the same experimental conditions. The neutral complex D-Ru 5a, involving one single TTFAQ, exhibits three absorption bands in the UVvis region at $464 \mathrm{~nm}\left(\varepsilon=16640 \mathrm{Lmol}^{-1} \mathrm{~cm}^{-1}\right), 394 \mathrm{~nm}\left(\varepsilon=12360 \mathrm{Lmol}^{-1} \mathrm{~cm}^{-1}\right)$ and $330 \mathrm{~nm}(\varepsilon$ $\left.=13300 \mathrm{Lmol}^{-1} \mathrm{~cm}^{-1}\right)$. The latter is ascribed to a metal-to-ligand charge transfer transition (MLCT) while the lowest energy absorption is assigned to a $\pi-\pi^{*}$ transition which is red shifted by $28 \mathrm{~nm}$ compared to the TTFAQ alkyne 3a $(436 \mathrm{~nm})$. Upon gradual oxidation to $\mathbf{5 a}^{\mathbf{2 +}}, \mathrm{D}^{2+}-\mathrm{Ru}$, a decrease of the absorption bands at 464 and $330 \mathrm{~nm}$ and the increase of the band at $394 \mathrm{~nm}$ bands occur together with the appearance of a broad absorption band at 660 
$\mathrm{nm}$ (Figure 6). A clear isobsestic point emerges at $510 \mathrm{~nm}$. The evolution of the UV-vis-NIR spectra of D-Ru 5a upon gradual oxidation strongly differs from the spectra obtained for 3a since for $\mathbf{3} \mathbf{a}^{2+}$ there is no absorption beyond $600 \mathrm{~nm}$. The broad band observed for D-Ru $\mathbf{5} \mathbf{a}^{2+}$, $\mathrm{TTFAQ}^{2+}-\mathrm{Ru}$, at $660 \mathrm{~nm}$ is reminiscent to what was observed with the TTF complex trans$\left[\mathrm{RuCl}\left(\mathrm{C} \equiv \mathrm{CMe}_{3} \mathrm{TTF}\right)(\mathrm{dppe})_{2}\right]^{22}$ where such a broad band was observed at an even lower energy $(1399 \mathrm{~nm})$ and was then ascribed to a SOMO-LUMO transition. Herein, it suggests that electronic interactions take place between the TTFAQ ${ }^{2+}$ and the $\mathrm{Ru}$ center along the acetylide linker. The TTFAQ dication acts as a good acceptor and the Ru center as an electron donor, thus the band observed at $660 \mathbf{n m}$ for $\mathbf{5 \mathbf { a } ^ { 2 + }}$ can be viewed as an intramolecular charge transfer (ICT) band. ${ }^{27}$ In accordance, upon oxidation to the tricationic state $\mathbf{5 a}^{3+}$, TTFAQ ${ }^{2+}$ $\mathrm{Ru}^{\mathrm{III}}$, this band disappears (Figure S3). The spectrum of $\mathbf{5 a}$ is fully recovered upon reduction of $\mathbf{5} \mathbf{a}^{3+}$. It is worth mentioning that compared with all the spectroelectrochemical investigations reported on TTFAQs up to now, none of them exhibit upon oxidation to the dicationic state such a broad absorption band at low energy.

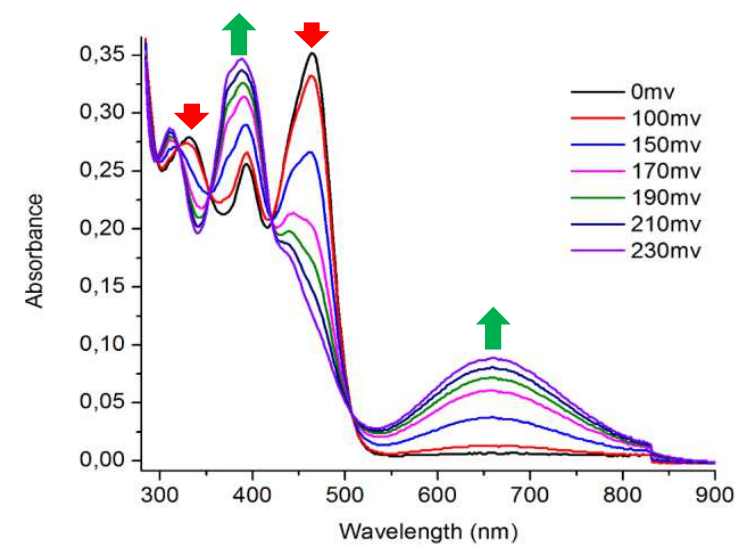

Figure 6. UV-vis-NIR monitoring of the electrochemical oxidation of $5 \mathbf{a}$ in $\mathrm{CH}_{2} \mathrm{Cl}_{2}$ containing $0.2 \mathrm{M} \mathrm{Bu}_{4} \mathrm{NPF}_{6}$, potentials are quoted vs SCE. 
Let us consider now the metal complexes involving two TTFAQ linked through the Ru bis(acetylide) linker anchored on the dithiole ring, D-Ru-D $6 \mathbf{b}$, or on the anthraquinodimethane moiety, A-Ru-A 8, of the organic electrophores. The UV-vis absorption spectrum of complex $\mathbf{6 b}$ shows two absorption band at low energies at 468 and $372 \mathrm{~nm}$ which are red shifted by $36 \mathrm{~nm}$ for the lowest energy one compared to the TTFAQethyne 3b (Figure 7a). This shift is more important than the one observed for the monosubstituted complex D-Ru 5a.
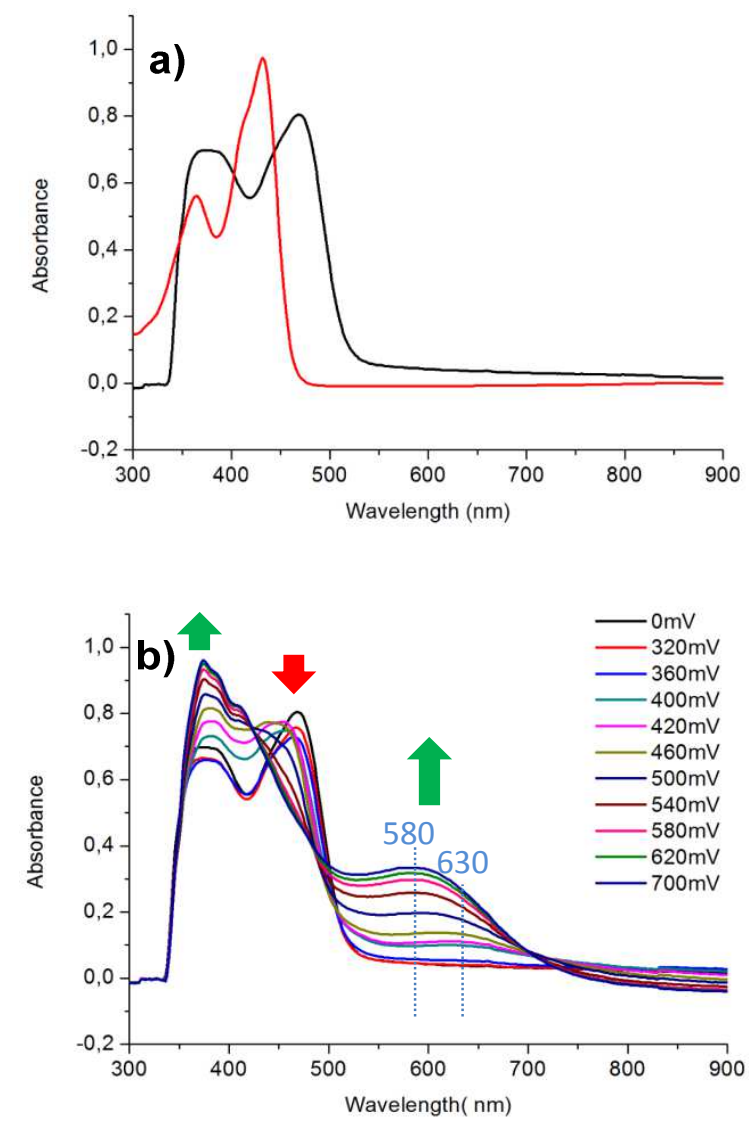

Figure 7. a) UV-vis-NIR spectra of D-Ru-D $\mathbf{6 b}$ (black line) and $\mathbf{3 b}$ (red line), b) UV-vis-NIR monitoring of the electrochemical oxidation of $\mathbf{6 b}$ in $\mathrm{CH}_{2} \mathrm{Cl}_{2}$ containing $0.2 \mathrm{M} \mathrm{Bu}_{4} \mathrm{NPF}_{6}$, potentials are quoted vs SCE.

Upon gradual oxidation of the bis-acetylide complex D-Ru-D $6 \mathbf{b}$ to the first oxidation potential corresponding to the oxidation of one TTFAQ moiety a broad band centered at 630 
$\mathrm{nm}$ appears (Figure 7b, Figure S4). This is reminiscent to what was observed for the mono acetylide complex D-Ru 5a and can be attributed to an Intramolecular Charge Transfer (ICT) from the Ru towards the TTFAQ ${ }^{2+}$ which behaves as an acceptor. Oxidation to the tetracation induces a further increase of this absorption band together with a shift towards higher energy as the maximum wavelengths reaches $580 \mathrm{~nm}$. This ICT band at $580 \mathrm{~nm}$ collapses upon oxidation of the metallic center (Figure S5). The spectrum of the neutral specie is recovered after sequential reduction of the pentacation.

The UV-vis-NIR spectrum of complex A-Ru-A 8 is similar to that of TTFAQ-ethyne 7 with two absorption bands at $450 \mathrm{~nm}$ and $382 \mathrm{~nm}$ (Figure 8a). Spectroelectrochemical investigations carried out on complex A-Ru-A 8 results in the decrease of the absorption band at $450 \mathrm{~nm}$ and the appearance of a broad band at $580 \mathrm{~nm}$. If we compare now the two complexes D-Ru-D 6b and A-Ru-A 8, a different evolution of the spectra upon oxidation to the tetracation is observed. For the complex D-Ru-D $\mathbf{6 b}$, upon oxidation to the dication $\mathbf{6} \mathbf{b}^{2+}$ the intensity of the lowest energy band gradually increases and a shift of $50 \mathrm{~nm}$ towards higher energies was detected while oxidizing the dication $6 \mathbf{b}^{2+}$ to the tetracation $6 \mathbf{b}^{4+}$. Whereas the oxidation of complex A-Ru-A 8 to the tetracation $\mathbf{8}^{4+}$ the oxidation leads only to the growth of the band centered at $580 \mathrm{~nm}$. The behavior observed for $\mathbf{6 b}$ is similar to that observed for the TTF complex, trans- $\left[\mathrm{Ru}\left(\mathrm{C} \equiv \mathrm{CMe}_{3} \mathrm{TTF}\right)_{2}(\mathrm{dppe})_{2}\right],{ }^{19}$ and consistent with the existence of electronic interplay between the two TTFAQ in $\mathbf{6 b}$ across the organometallic linker. 

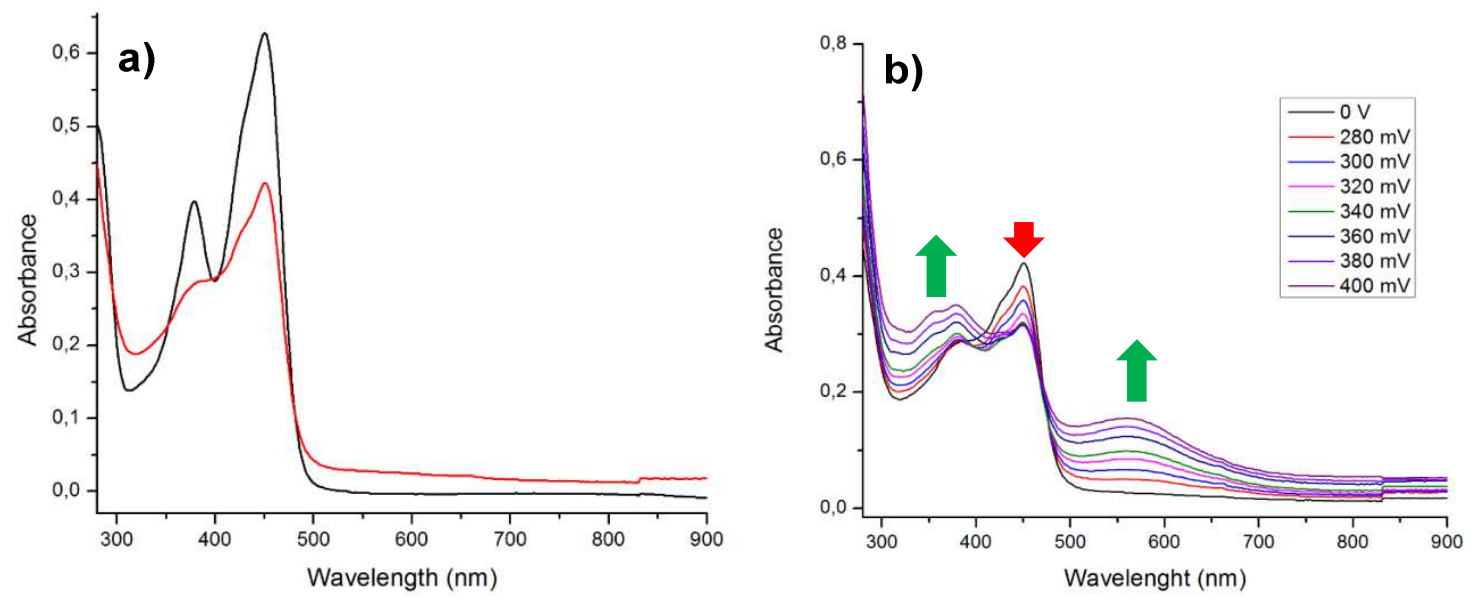

Figure 8. a) UV-vis-NIR spectra of A-Ru-A 8 in red and 7 in black, b) UV-vis-NIR monitoring of the electrochemical oxidation of 8 in $\mathrm{CH}_{2} \mathrm{Cl}_{2}$ containing $0.2 \mathrm{M} \mathrm{Bu}_{4} \mathrm{NPF}_{6}$, potentials are quoted $v s$ SCE.

\section{Conclusion}

In summary, we have reported here the synthesis of three types of electroactive ruthenium complexes bearing either one or two extended tetrathiafulvalene, TTFAQ, connected to a Ru center by an acetylide linker. The influence of the anchoring site of the linker on the TTFAQ core on the electronic coupling between the different electrophores has been investigated by a combination of electrochemical and spectroelectrochemical investigations. In all three complexes (D-Ru, D-Ru-D and A-Ru-A) electronic interactions between the TTFAQ and the $\mathrm{Ru}$ have been evidenced. However intramolecular interactions between two TTFAQs are only observed when a $\mathrm{Ru}$ bis(acetylide) linker is localized on the dithiole rings of the TTFAQ moieties (D-Ru-D). These results demonstrate how important is the localization of the linker between two TTFAQ units for allowing intramolecular electronic coupling between these two electrophores. 


\section{Experimental section}

General. NMR spectra were recorded at room temperature using $\mathrm{CDCl}_{3}$ unless otherwise noted. Chemical shifts are reported in ppm and ${ }^{1} \mathrm{H}$ NMR spectra were referenced to residual $\mathrm{CHCl}_{3}(7.26 \mathrm{ppm}),{ }^{13} \mathrm{C} \mathrm{NMR}$ spectra were referenced to $\mathrm{CHCl}_{3}(77.2 \mathrm{ppm})$ and ${ }^{31} \mathrm{P}$ NMR to $\mathrm{H}_{3} \mathrm{PO}_{4}$. Mass spectra were recorded with Agilent 6510 instrument for organics compounds, and with Thermo-fisher Q-Exactive instrument for complexes by the Centre Régional de Mesures Physiques de l'Ouest, Rennes. CVs were carried out on a $10^{-3} \mathrm{M}$ solution of complex in $\mathrm{CH}_{2} \mathrm{Cl}_{2}-\left[\mathrm{NBu}_{4}\right]\left[\mathrm{PF}_{6}\right] 0.1 \mathrm{M}$. CVs were recorded on a Biologic SP-50 Instruments at $0.1 \mathrm{Vs}^{-1}$ on a platinum disk electrode. Potentials were measured versus $\mathrm{KCl}$ Saturated Calomel Electrode (SCE), calibrated using internal ferrocene. The spectroelectrochemical setup was performed in $\mathrm{CH}_{2} \mathrm{Cl}_{2}-\left[\mathrm{NBu}_{4}\right]\left[\mathrm{PF}_{6}\right] 0.2 \mathrm{M}$ using a Pt grid as the working electrode, a Pt wire as the counter electrode and SCE reference electrode. A Shimatzu 3600 spectrophotometer was employed to record the UV-vis-NIR spectra. Column chromatography was performed using silica gel Merck 60 (70-260 mesh). All other reagents and materials from commercial sources were used without further purification. The complexes were synthetized under an argon atmosphere using standard Schlenk techniques. The solvents were purified and dried by standard methods. The cis- $\left[\operatorname{RuCl}_{2}(\mathrm{dppe})_{2}\right]^{28}$ and TTFAQ $\mathbf{1 a}{ }^{14}$ and $7^{29}$ were synthesized according to literature procedure. The synthesis of $\mathbf{1 b}$ is described in supporting information.

Trimethylsilylethynyl-TTFAQ 2(a-b). In a Schlenk tube, the iodo-TTFAQ (550 mg for 1a and $650 \mathrm{mg}$ for $\mathbf{1 b}, 1 \mathrm{mmol})$ together with $\mathrm{PdCl}_{2}\left(\mathrm{PPh}_{3}\right)_{2}(74 \mathrm{mg}, 0.1 \mathrm{mmol})$ and $\mathrm{CuI}(20 \mathrm{mg}$, $0.1 \mathrm{mmol}$ ) were placed under vacuum for 5 hours. Then the solids were solubilized in $40 \mathrm{~mL}$ of dry THF and $0.5 \mathrm{~mL}$ of diisopropylamine and trimethylsilylacetylene $(0.25 \mathrm{~mL}, 1.75$ mmol) were quickly added. The reaction mixture was stirred at room temperature for 48 
hours. The solvent was evaporated and the resulting solid was purified by flash chromatography on silica gel using dichloromethane/petroleum ether (2:8) as eluent. TTFAQ 2a-b were obtained as yellow solid in 70 and $80 \%$ yield respectively.

2a mp > 220 ${ }^{\circ} \mathrm{C}:{ }^{1} \mathrm{HNMR} \delta 7.64(\mathrm{~m}, 2 \mathrm{H}), 7.56(\mathrm{~m}, 2 \mathrm{H}), 7.26(\mathrm{~m}, 4 \mathrm{H}), 2.10(\mathrm{~s}, 3 \mathrm{H}), 1.93(\mathrm{~s}$, $6 \mathrm{H}), 0.20(\mathrm{~s}, 9 \mathrm{H}) .{ }^{13} \mathrm{C}$ NMR 136.7, 126.0, 125.6, 125.3, 120.8, 108.2, 101.6, 94.6, 15.2, 13.1, 0.2; HRMR calcd for $\mathrm{C}_{28} \mathrm{H}_{26} \mathrm{~S}_{4} \mathrm{Si}$ : 518.0681. Found : 518.0677; Anal. calcd. for $\mathrm{C}_{28} \mathrm{H}_{26} \mathrm{~S}_{4} \mathrm{Si}$ : C, 64.82; H, 5.05; S, 24.72\%. Found C, 64.52; H, 5.11; S, 24.25\%.

2b mp > 220 ${ }^{\circ} \mathrm{C} ;{ }^{1} \mathrm{HNMR}: \delta 7.6(\mathrm{~m}, 2 \mathrm{H}), 7.54(\mathrm{~m}, 2 \mathrm{H}), 7.29(\mathrm{~m}, 4 \mathrm{H}), 2.39(\mathrm{~s}, 6 \mathrm{H}, 2(\mathrm{SMe}))$, 2.12 (s, 3H, Me), 0.20 (s, 9H, Si(Me) $\left.)_{3}\right) ;{ }^{13} \mathrm{C}$ NMR 136.7, 134.8, 134.7, 134.6, 134.5, 132.1, $130.9,126.2,126.2,126.1,125.9,125.6,125.4,125.4,125.4,123.8,122.9,108.3,101.9$, 94.4, 19.2, 15.2; HRMR calcd for $\mathrm{C}_{28} \mathrm{H}_{26} \mathrm{~S}_{6} \mathrm{Si}: 582.0123$. Found : 582.0127; Anal. calcd. for $\mathrm{C}_{28} \mathrm{H}_{26} \mathrm{~S}_{6} \mathrm{Si}: \mathrm{C}, 57.69 ; \mathrm{H}, 4.50 \%$. Found C, 58.05; H, $4.25 \%$.

TTFAQ-ethyne 3a-b To a solution of $\mathbf{2}(1 \mathrm{mmol}, 520 \mathrm{mg}$ for $\mathbf{2 a}$ and $580 \mathrm{mg}$ for $\mathbf{2 b}$ ) in 100 $\mathrm{mL}$ of methanol KF (100 mg, $1.7 \mathrm{mmol}$ ) was added. The reaction mixture was stirred for 15 $\mathrm{h}$ under argon at room temperature. The solvent was removed in vacuo and the residue was purified by column chromatography on silica gel using dichloromethan/petroleum ether (1/9) as eluent. TTFAQ-ethyne 3a-b were obtained as yellow powder in 98 and $94 \%$ yield respectively.

3a mp > 220 $\mathrm{C} ;{ }^{1} \mathrm{H}$ NMR: $\delta 7.65(\mathrm{~m}, 2 \mathrm{H}), 7.56(\mathrm{~m}, 2 \mathrm{H}), 7.27(\mathrm{~m}, 4 \mathrm{H}), 3.29(\mathrm{~s}, 1 \mathrm{H}), 2.12(\mathrm{~s}$, 3H), $1.93(\mathrm{~s}, 6 \mathrm{H}) ;{ }^{13} \mathrm{C}$ NMR $\delta 137.64,135.27,134.72,133.86,131.05,126.12,125.72$, $125.64,125.42,125.33,125.24,123.48,120.89,106.99,83.54,74.36,15.12,13.09 ; \mathrm{IR}(\mathrm{KBr})$ : $v_{\mathrm{C} \equiv \mathrm{C}}=2095 \mathrm{~cm}^{-1}$; HRMS calcd for $\mathrm{C}_{25} \mathrm{H}_{18} \mathrm{~S}_{4}:$ 446.0286. Found : 446.0281; Anal. calcd. for $\mathrm{C}_{25} \mathrm{H}_{18} \mathrm{~S}_{4}:$ C, 67.23; H, 4.06; S, 28.71\%. Found C, 66.57; H, 4.18; S, 28.69\%. 
3b mp > 220 ${ }^{\circ} \mathrm{C} ;{ }^{1} \mathrm{HNMR}: \delta 7.57(\mathrm{~m}, 4 \mathrm{H}), 7.3(\mathrm{~m}, 4 \mathrm{H}), 3.31(\mathrm{~s}, 1 \mathrm{H} ; \equiv \mathrm{CH}), 2.39(\mathrm{~s}, 6 \mathrm{H}$, 2(SMe)), 2.13 (s, 3H; Me); ${ }^{13} \mathrm{CNMR}: \delta$ 137.6, 134.7, 134.7, 134.6, 134.6, 131.8, 131.1, $126.3,126.2,125.9,125.6,125.5,125.4,125.3,123.7,123.0,107.1,83.7,74.1,19.2,15.1$; IR $(\mathrm{KBr}): v_{\mathrm{C} \equiv \mathrm{C}}=2096 \mathrm{~cm}^{-1}$; HRMS calcd for $\mathrm{C}_{25} \mathrm{H}_{18} \mathrm{~S}_{6}: 509.9727$. Found : 509.9727; Anal. calcd. for $\mathrm{C}_{25} \mathrm{H}_{18} \mathrm{~S}_{6}$ : C, 58.78; H, 3.55; S, 37.66\%. Found C, 58.42; H, 3.17; S, 38.13\%

Complexes 5a-b: A solution of TTFAQ 3 (0.6 mmol, $270 \mathrm{mg}$ for $\mathbf{3 a}$ and $310 \mathrm{mg}$ for $\mathbf{3 b})$ in 15 $\mathrm{mL}$ of $\mathrm{CH}_{2} \mathrm{Cl}_{2}$ was added to a solution of [ClRu(dppe) $\left.)_{2}\right][\mathrm{OTf}](480 \mathrm{mg}, 0.48 \mathrm{mmol})$ in $15 \mathrm{~mL}$ of $\mathrm{CH}_{2} \mathrm{Cl}_{2}$. After $24 \mathrm{~h}$ of stirring at room temperature, the solvent was removed in vacuo and the precipitate was washed with diethyl ether. The dark green precipitate, the vinylidene derivative $[4][\mathrm{TfO}]$ was used in the next step without further purification. ${ }^{31} \mathrm{P}$ NMR (121 $\left.\mathrm{MHz}, \mathrm{CDCl}_{3}\right) \delta 46.5(\mathrm{~s}, 4 \mathrm{P})$ for $\mathbf{4 a}$ and $46.5(\mathrm{~s}, 4 \mathrm{P})$ for $\mathbf{4 b}$. The vinylidene derivative [4][TfO] was dissolved in $30 \mathrm{~mL}$ of $\mathrm{CH}_{2} \mathrm{Cl}_{2}$ and $\mathrm{NEt}_{3}(1 \mathrm{~mL})$ was added an immediate change of color from green to yellow was observed. The reaction mixture was stirred at room temperature for $2 \mathrm{~h}$ and the solvent was removed under vacuo. The resulting powder was washed with distilled water (3x $20 \mathrm{~mL})$ and pentane (3x $20 \mathrm{~mL})$. Complex 5a was obtained as a yellow powder in $40 \%$ yield. ${ }^{1} \mathrm{H}$ NMR: $\delta 7.80(\mathrm{~m}, 8 \mathrm{H}), 7.67(\mathrm{~m}, 4 \mathrm{H}), 7.30-7.24(\mathrm{~m}, 9 \mathrm{H})$, $7.13(\mathrm{~m}, 12 \mathrm{H}), 6.91(\mathrm{~m}, 15 \mathrm{H}), 2.78(\mathrm{~m}, 4 \mathrm{H}), 2.54(\mathrm{~m}, 4 \mathrm{H}), 1.95(\mathrm{~s}, 6 \mathrm{H}), 1.28(\mathrm{~s}, 3 \mathrm{H}) ;{ }^{31} \mathrm{P}$ NMR: $\delta 50.7(\mathrm{~m}, 2 \mathrm{P}), 50.1(\mathrm{~m}, 2 \mathrm{P}) ;{ }^{13} \mathrm{C}$ NMR $\delta 136.5,135.7,135.4,135.3,134.9,134.8$, $133.9,132.1,129.5,128.4,127.5,126.7,125.7,125.6,125.5,125.3,125.2,125.1,121.8$, $120.8,120.8,120.1,114.0,104.8,34.1,30.8,22.3,14.0,13.5,13.1 . \mathrm{IR}(\mathrm{KBr}): v_{\mathrm{C} \equiv \mathrm{C}}=2044$ $\mathrm{cm}^{-1}$; HRMS calcd for $\mathrm{C}_{77} \mathrm{H}_{65} \mathrm{ClP}_{4} \mathrm{RuS}_{4}$ : 1378.1646; Found : 1378.1654 .

5b ${ }^{1} \mathrm{H}$ NMR $\left(\mathrm{CD}_{2} \mathrm{Cl}_{2}\right) \delta$ 7.75-7.00 (m, 48H); $2.84(\mathrm{~m}, 4 \mathrm{H}) ; 2.66(\mathrm{~m}, 4 \mathrm{H}) ; 2.45(\mathrm{~s}, 3 \mathrm{H}) ; 2.43(\mathrm{~s}$, $3 \mathrm{H}) ; 1.32(\mathrm{~s}, 3 \mathrm{H}) ;{ }^{31} \mathrm{P}$ NMR $\left(\mathrm{CD}_{2} \mathrm{Cl}_{2}\right) \delta 49.7(\mathrm{~m}, 2 \mathrm{P}) ; 48.6(\mathrm{~m}, 2 \mathrm{P}) ;{ }^{13} \mathrm{C} \mathrm{NMR}\left(\mathrm{CD}_{2} \mathrm{Cl}_{2}\right) \delta$ 
$136.7,136.4,136.3,135.8,135.2,135.2,134.9,134.8,134.7,134.6,134.5,134.23,134.2$, $134.1,134.0,133.9,129.8,129.4,128.7,128.6,127.5,127.4,126.83,126.8,126.2,125.8$, $125.7,125.4,125.3,124.5,119.5,114.0,104.1,30.7,18.9,13.4 ; \mathrm{IR}(\mathrm{KBr}): v_{\mathrm{C}=\mathrm{C}}=2044 \mathrm{~cm}^{-1}$; HRMS calcd for $\mathrm{C}_{77} \mathrm{H}_{65} \mathrm{ClP}_{4} \mathrm{RuS}_{6}$ : 1442.1087; Found : 1442.1102.

Complexes 6a-b and 8: To a solution of TTFAQ-ethyne (0.87 mmol, $390 \mathrm{mg}$ for 3a, $440 \mathrm{mg}$ for $\mathbf{3 b}$ and $460 \mathrm{mg}$ for 7), cis-[RuCl $\left.2(\mathrm{dppe})_{2}\right](0.35 \mathrm{mmol}, 338 \mathrm{mg})$ and NaPF6 (1.74 mmol, $300 \mathrm{mg})$ in $\mathrm{CH}_{2} \mathrm{Cl}_{2}(40 \mathrm{~mL})$, freshly distilled $\mathrm{NEt}_{3}(1 \mathrm{~mL})$ was added and the solution was stirred at room temperature for 15 hours. The reaction mixture was filtered and the precipitate was washed with distilled water $(4 \times 40 \mathrm{~mL})$ and dry $\mathrm{Et}_{2} \mathrm{O}(3 \mathrm{x} 40 \mathrm{~mL})$. Complexes $6 \mathbf{a}-\mathbf{b}$ and 8 were isolated as yellow powders in 55\% yield, $60 \%$ and $45 \%$ yields respectively. Complex 6a was insoluble in common organic solvent. Complex $\mathbf{6 b}$ was crystallized by slow diffusion of pentane into a solution of $\mathbf{6 b}$ in $\mathrm{CHCl}_{3}$ and carbon disulfide (3/1).

6a IR $(\mathrm{KBr}): v_{\mathrm{C} \equiv \mathrm{C}}=2044 \mathrm{~cm}^{-1}$; HRMS calcd for $\mathrm{C}_{102} \mathrm{H}_{82} \mathrm{P}_{4} \mathrm{RuS}_{8}$ : 1788.2170; Found :1788.2168; Anal. calcd. for $\left[\mathrm{C}_{102} \mathrm{H}_{82} \mathrm{P}_{4} \mathrm{RuS}_{4}+{ }_{0.5} \mathrm{CH}_{2} \mathrm{Cl}_{2}\right]$ : C, 67.21; H, 4.57. Found C, 67.34; $\mathrm{H}, 4.45$.

6b ${ }^{1} \mathrm{HNMR}\left(\mathrm{CD}_{2} \mathrm{Cl}_{2}\right) \delta 7.64(\mathrm{~m}, 5 \mathrm{H}), 7.49(\mathrm{~m}, 5 \mathrm{H}), 7.31(\mathrm{~m}, 21 \mathrm{H}), 7.15(\mathrm{~m}, 9 \mathrm{H}), 7.00(\mathrm{~m}, 6 \mathrm{H})$, $2.62\left(\mathrm{~m}, 8 \mathrm{H},(\mathrm{dppe})_{2}\right), 2.43(\mathrm{~s}, 6 \mathrm{H}, 2(\mathrm{SMe})), 2.39$ (s, 6H, 2(SMe)), 1.24(s, 6H, 2(Me)); ${ }^{31} \mathrm{P}$ NMR $\left(\mathrm{CD}_{2} \mathrm{Cl}_{2}\right) \quad \delta 51.8(\mathrm{~s}, 4 \mathrm{P}) ;{ }^{13} \mathrm{C} \mathrm{NMR}\left(\mathrm{CD}_{2} \mathrm{Cl}_{2}\right): \delta(\mathrm{ppm}) \quad 136.0,135.7,135.3,134.5$, $134.1,134.0,129.7,129.0,127.3,126.1,126.0,125.7,125.6,125.5,125.3,121.4,119.5$, 114.4, 106.3, 31.5, 19.2, 14.1; IR (KBr): $v_{\mathrm{C} \equiv \mathrm{C}}=2044 \mathrm{~cm}^{-1}$; HRMS calcd for $\mathrm{C}_{102} \mathrm{H}_{82} \mathrm{P}_{4} \mathrm{RuS} \mathrm{S}_{12}$ : 1916.1053. Found : 1916.1062; Anal. calcd. for $\mathrm{C}_{102} \mathrm{H}_{82} \mathrm{P}_{4} \mathrm{RuS}_{12}$ : C, 63.89; H, 4.31; S, 20.06\%. Found C, 63.74; H, 4.38; S, $19.51 \%$.

$8^{31} \mathrm{P}$ NMR $\delta 53.9(\mathrm{~s}, 4 \mathrm{P}) ; \mathrm{IR}(\mathrm{KBr}): \mathrm{v}_{\mathrm{C} \equiv \mathrm{C}}=2053 \mathrm{~cm}^{-1}$; HRMS calcd for $\mathrm{C}_{104} \mathrm{H}_{86} \mathrm{P}_{4} \mathrm{RuS}_{12}$ : 1944.13667. Found : 1944.1366. Anal. calcd. for $\left[\mathrm{C}_{104} \mathrm{H}_{86} \mathrm{P}_{4} \mathrm{RuS}_{12}+\mathrm{CH}_{2} \mathrm{Cl}_{2}\right]: \mathrm{C}, 62.11 ; \mathrm{H}$, 4.37; S, 18.95\%. Found C, 62.57; H, 4.36; S, 19.24\%. 
Crystallography. Single-crystal diffraction data were collected on a D8 VENTURE Bruker AXS diffractometer (Mo- K $\alpha$ radiation, $\lambda=0.71073 \AA$ ). The structure were solved by dualspace algorithm using the SHELXT program, ${ }^{30}$ and then refined with full-matrix least-square methods based on F2 (SHELXL-2014). ${ }^{31}$ All non-hydrogen atoms were refined with anisotropic atomic displacement parameters. $\mathrm{H}$ atoms were finally included in their calculated positions. Details of the final refinements are given in Table 2. 
Table 2 Crystallographic data for TTFAQ 3a and trans- $\left[\mathrm{Ru}(\mathrm{C} \equiv \mathrm{CDTTFAQ})_{2}(\mathrm{dppe})_{2}\right] \mathbf{6 b}$.

\begin{tabular}{|c|c|c|}
\hline Compound & $\mathbf{3 a}$ & $\mathbf{6 b}$ \\
\hline Formulae & $\mathrm{C}_{25} \mathrm{H}_{18} \mathrm{~S}_{4}, \mathrm{CHCl}_{3}$ & $\mathrm{C}_{102} \mathrm{H}_{82} \mathrm{P}_{4} \mathrm{RuS}_{12}, 3\left(\mathrm{CHCl}_{3}\right)$ \\
\hline $\mathrm{FW}\left(\mathrm{g} \cdot \mathrm{mol}^{-1}\right)$ & 566.00 & 2275.45 \\
\hline System & triclinic & triclinic \\
\hline Space group & P-1 & $\mathrm{P}-1$ \\
\hline $\mathrm{a}(\AA)$ & $8.9594(10)$ & $10.7345(8)$ \\
\hline $\mathrm{b}(\AA)$ & $9.6392(11)$ & $13.9086(11)$ \\
\hline c $(\AA)$ & $15.5389(16)$ & $18.0123(15)$ \\
\hline$\alpha(\operatorname{deg})$ & $76.139(4)$ & $99.254(3)$ \\
\hline$\beta(\operatorname{deg})$ & $83.939(4)$ & $103.778(3)$ \\
\hline$\gamma(\operatorname{deg})$ & $79.428(4)$ & $93.974(3)$ \\
\hline$V\left(\AA^{3}\right)$ & $1278.1(2)$ & $2561.6(4)$ \\
\hline $\mathrm{T}(\mathrm{K})$ & $150(2)$ & $150(2)$ \\
\hline $\mathrm{Z}$ & 2 & 1 \\
\hline$D_{\text {calc }}\left(\right.$ g.cm $\left.{ }^{-1}\right)$ & 1.471 & 1.475 \\
\hline$\mu\left(\mathrm{mm}^{-1}\right)$ & 0.700 & 0.743 \\
\hline Total refls & 24694 & 55584 \\
\hline Abs corr & multiscan & multiscan \\
\hline Uniq refls $\left(\mathrm{R}_{\mathrm{int}}\right)$ & $5869(0.0500)$ & $11719(0.0430)$ \\
\hline Uniq refls $(\mathrm{I}>2 \sigma(\mathrm{I}))$ & 4793 & 9646 \\
\hline $\mathrm{R}_{1, \mathrm{w}} \mathrm{R}_{2}$ & $0.0583,0.1376$ & $0.0741,0.2008$ \\
\hline $\mathrm{R}_{1, \mathrm{wR}}$ (all data) & $0.0732,0.1465$ & $0.0907,0.2226$ \\
\hline GOF & 1.075 & 1.031 \\
\hline
\end{tabular}

\section{Notes}

The authors declare no competing financial interests

Supporting Information Available. Experimental procedure for the synthesis of $\mathbf{1 b},{ }^{31} \mathrm{P}$ NMR spectrum of complex 5a. Additional UV-vis-NIR figures for complexes $\mathbf{5 a}$ and $\mathbf{6 b}$ and DPV for complex 8. X-ray crystallographic files in CIF format. This material is available free of charge on the ACS Publications website at DOI: 


\section{References}

${ }^{1}$ Martín, N.; Sanchez, L.; Herranz, M. A.; Illescas, B.; Guldi, D. M. Acc. Chem. Res. 2007, 40, 1015-1024.

${ }^{2}$ Lopez-Andarias, J.; Rodriguez, M. J.; Atienza, C.; Lopez, J. L.; Mikie, T.; Casado, S.; Seki, S.; Carrascosa, J. L.; Martín, N. J. Am. Chem. Soc. 2015, 137, 893-897.

${ }^{3}$ (a) Isla, H.; Gallego, M.; Pérez, E. M.; Viruela, R.; Ortí, E.; Martín, N. J. Am. Chem. Soc. 2010, 132, 1772-1773. (b) Bivaud, S.; Goeb, S.; Croué, V.; Dron, P. I.; Allain, M.; Salle, M. J. Am. Chem. Soc. 2013, 135, 10018-10021.

${ }^{4}$ Moreira, L.; Calbo, J.; Calderon, R. M. K.; Santos, J.; Illescas, B. M.; Arago, J.; Nierengarten, J.-F.; Guldi, D. M.; Orti, E.; Martín, N. Chem. Sci. 2015, 6, 4426-4432.

${ }^{5}$ Shao, M.; Dongare, P.; Dawe, L. N.; Thompson, D. W.; Zhao, Y. Org. Lett. 2010, 12, $3050-3053$.

${ }^{6}$ Akiba, K.; Kiyofumi I.; Naoki I. Bull. Chem. Soc. Jpn. 1978, 51, 2684-2689.

${ }^{7}$ Bryce, M. R.; Moore, A. J. Synthetic metals 1988, 25, 203-205.

${ }^{8}$ Bryce, M. R.; Moore, A. J.; Hasan, M.; Ashwell, G. J.; Fraser, A. T.; Clegg, W.; Hursthouse, M. B.; Karaulov, A.I. Angew. Chem. Int. Ed. Engl. 1990, 29, 1450-1452.

${ }^{9}$ Gruhn, N. E.; Macías-Ruvalcaba, N. A.; Evans, D. H. Langmuir 2006, 22, 10683-10688.

${ }^{10}$ Perepichka, D. F., Bryce, M. R.; Perepichka, I. F.; Lyubchik, S. B.; Christensen, C. A.; Godbert, N.; Batsanov, A. S.; Levillain, E.; Mclnnes, E. J. L.; Zhao, J. P. J. Am. Chem. Soc. 2002, 124, 14227-14238.

11 (a) Pérez, E. M.; Sánchez, L.; Fernández, G.; Martin, N. J. Am. Chem. Soc. 2006, 128, 7172-7173. (b) Pérez, E. M.; Capodilupo, A. L.; Fernández, G.; Sánchez, L.; Viruela, E. O.; Orti, E.; Bietti, M.; Martín, N. Chem. Commun. 2008, 4567-4569. (c) Fernández, G.; Pérez, E. M.; Sánchez, L.; Martín, N. Angew. Chem., Int. Ed. 2008, 47, 1094-1097. (d) Canevet, 
D.; Gallego, M.; Isla, H.; de Juan, A.; Pérez, E. M.; Martín, N. J. Am. Chem. Soc. 2011, 133, 3184-3190.

${ }^{12}$ Bastien, G.; Dron, P. I.; Vincent, M.; Canevet, D.; Allain, M.; Goeb, S.; Sallé, M. Org. Lett. 2016, $15,5856-5859$.

${ }^{13}$ Ogi, D.; Fujita, Y.; Mori, S.; Shirahata, T.; Misaki, Y. Org. Lett. 2016, 15, 5868-5871.

${ }^{14}$ Díaz, M. C., Illescas, B. M.; Martin, N.; Perepichka, I. F.; Bryce, M. R.; Levillain, E.; Viruela, R.; Orti, E. Chem. Eur. J. 2006, 12, 2709-2721.

${ }^{15}$ Martín, N.; Perez, I.; Sanchez, L.; Seoane, C. J. Org. Chem. 1997, 62, 870-877.

${ }^{16}$ Díaz, M. C; Illescas, B. M.; Seoane, C.; Martín, N. J. Org. Chem. 2004, 69, 4492-4499.

${ }^{17}$ Shao, M.; Guang, C.; Zhao, Y. Synlett 2008, 3, 371-376.

${ }^{18}$ Illescas, B. M.; Santos, J.; Wielopolski, Atienza, C.; Martin, N.; Guldi, D. M. Chem. Commun. 2009, 5374-5376.

${ }^{19}$ (a) Vacher, A.; Barrière, F.; Piekara-Sady, L.; Roisnel, T.; Lorcy, D. Organometallics 2011, 30, 3570-3578. (b) Vacher, A.; Barrière, F.; Lorcy, D. Organometallics 2013, 32, $6130-6135$.

${ }^{20}$ (a) Colbert, M. C. B.; Lewis, J.; Long, N. J.; Raithby, P. R.; White, A. J. P.; Williams, D. J. J. Chem. Soc., Dalton Trans. 1997, 99-104. (b) Jones, N. D.; Wolf, M. O.; Giaquinta, D. M. Organometallics 1997, 16, 1352-1354. (c) Lebreton, C.; Touchard, D.; Le Pichon, L.; Daridor, A.; Toupet, L.; Dixneuf, P. H. Inorg. Chim. Acta 1998, 272, 188-196.

${ }^{21}$ Garcia, R.; Herranz, Á.; Torres, R.; Bouit, P.-A.; Delgado, J. L.; Calbo, J.; Viruela, P. M.; Orti, E.; Martin, N. J. Org. Chem. 2012, 77, 10707-10717.

${ }^{22}$ Vacher, A.; Barrière, F.; Roisnel, T.; Lorcy, D. Chem. Commun. 2009, 7200-7202.

${ }^{23}$ Younus, M.; Long, N. J.; Raithby, P. R.; Lewis, J.; Page, N. A.; White, A. J. P.; Williams, D. J.; Colbert, M. C. B.; Hodge, A. J.; Khan, M. S.; Parker, D. G. J. Organomet. Chem. 1999, 578, 198-209. 
${ }^{24}$ Martín, N.; Sánchez, L.; Seoane, C.; Ortí, E.; Viruela, P. M.; Viruela, R. J. Org. Chem. 1998, 63, 1268-1279.

${ }^{25}$ Pérez, I.; Liu, S. G., Martín, N.; Echegoyen, L. J. Org. Chem. 2000, 65, 3796-3803.

${ }^{26}$ Christensen, C. A.; Bryce, M. R.; Batsanov, A. S.; Becher, J. Org. Biomol. Chem. 2003, 1, $511-522$.

${ }^{27}$ Liu, S.-G.; Pérez, I.; Martín, N.; Echegoyen, L. J. Org. Chem. 2000, 65, 9092-9102.

28 Chaudret, B.; Commenges, G.; Poilblanc, R. J. Chem. Soc., Dalton Trans. 1984, $1635-1639$.

${ }^{29}$ Shao, M.; Chen, G.; Zhao, Y. M. Synlett 2008, 371-376.

${ }^{30}$ Sheldrick G. M., Acta Cryst. 2015, A71, 3-8.

${ }^{31}$ Sheldrick G. M., Acta Cryst. 2015, C71, 3-8. 